\title{
Impact of cormorant (Phalacrocorax carbo sinensis L.) colonies on microbial pollution in lakes
}

\author{
Piotr Klimaszyk ${ }^{1}$, Piotr Rzymski \\ ${ }^{1}$ Department of Water Protection, A. Mickiewicz University, Umultowska 89, 61-614 Poznań, Poland, \\ e-mail: pklim@amu.edu.pl (corresponding author) \\ ${ }^{2}$ Department of Biology and Environmental Protection, University of Medical Sciences, Rokietnicka 8, 60-806, Poznań, Poland, \\ e-mail: rzymskipiotr@ump.edu.pl
}

\begin{abstract}
During 2009-2011 we investigated the effect of perennial and roosting cormorant (Phalacrocorax carbo sinensis) colonies on microbial pollution in 3 lakes: Góreckie (Greater Poland National Park), Chrzypsko (Greater Poland Province) and Ostrowiec (Drawa National Park). On Lake Góreckie cormorants formed a roosting colony ( $<200$ individuals) that inhabited part of the lake shore. On Lake Chrzypsko a new breeding colony was formed ( 3 nests) while the breeding colony on Lake Ostrowiec, established over 40 years ago, consisted of over 170 breeding pairs. In the case of Lake Ostrowiec, high pollution with coliform bacteria (including Escherichia coli) was observed. Compared to the control station the significantly higher Most Probable Number (MPN) of coliform bacteria was found in groundwater under the colony. It was found that bacterial counts decreased in the direction of the centre of the water body with the highest numbers noted in the lake samples collected within the colony boundaries. Furthermore, seasonal variations in coliform bacteria were also observed with maximum densities during the breeding season. Similar trends were observed for the roosting colony on Lake Góreckie while for the newly forming colony on Lake Chrzypsko increased density of investigated bacteria was noted only in groundwater.
\end{abstract}

Key words: cormorant, microbial contamination, coliform bacteria, Escherichia coli

\section{Introduction}

Freshwater pollution may be accelerated by waterfowl. Excrement of water birds is a source of biogenic elements like nitrogen and phosphorus, which are responsible for increasing the fertility of lakes (Gwiazda 2011; Klimaszyk 2012) as well as encouraging the growth of pathogenic microorganisms (Kuhn et al. 2002; Wiśniewska et al. 2007a). For the purpose of monitoring the sanitary quality of surface waters, faecal coliforms and E. coli have traditionally served as indicators of water quality or as a means of classifying waters in order to protect public health. Waterfowl can serve as reservoirs of pathogenic bacteria such as Escherichia coli, harmful for humans (Kuhn et al.2002; Dobbin et al. 2005). Large numbers of bacteria of bird origin reveal genetic resistance to antimicrobial drugs. The effect of the microbial contamination of soils and waters depends on the number of birds, their species, the season and the duration of their stay in a water reservoir (Alderisio and DeLuca 1999; Wiśniewska et al. 2007a). The growing population of cormorants (Phalacrocorax carbo sinensis L.) in Europe and the occurrence of colonies in new areas have raised concerns as to the consequences of their presence in the environment. Cormorants are a very important intermediate link in some food chains and a factor that facilitates the dislocation of matter between aquatic and terrestrial ecosystems (Marion et al. 1994). During the breeding season, cormorants feeding in the aquatic environment transport a large amount faeces to colonies situated on land (Kameda et al. 2006) but near the lake shores. Loads of allochtonic matter delivered by birds to the land ecosystem can result in a significant enrichment of soil and plants with $\mathrm{N}$ and $\mathrm{P}$ (Anderson and Polis 1999; Mulder and Keall 2001), factors that usually limit primary production (Vitousek and Howwarth 1991). Increased concentrations of $\mathrm{N}$ and $\mathrm{P}$, as well as bacteria deposited by birds within the colony area, can be transferred together with groundwater 
(Jones 2003) or by surface runoff (Klimaszyk 2012) and contribute to contamination of lakes and rivers. In this paper the relationship between the number of cormorants inhabiting a colony and the density of bacteria in groundwater and surface water was investigated. Furthermore the range of microbial contamination of the lake water in relation to colony size was also analysed.

\section{Material and methods}

\section{The lakes and cormorant colonies}

Lake Chrzypsko is a large (288 ha), but not very deep (maximum depth $15 \mathrm{~m}$ ) water reservoir. The physical and chemical properties of the lake water are typical for the state of moderate eutrophy (Klimaszyk 2012). Of the three islands located on the lake, two are inhabited by cormorants. Our investigations were conducted on the southernmost island (1.2 ha) of the lake. Since 2005 cormorants have been observed on the island - ranging from several to one hundred individuals roosting on the north island shore. In 2009 and 2010 four breeding pairs were noted. The second perennial and abundant (over 150 breeding pairs) cormorant colony is located in the northern part of the lake and has already been investigated earlier (Klimaszyk 2012).
Lake Góreckie, located in the Greater Poland National Park is a large and deep reservoir (an area of $103 \mathrm{ha}$, a maximum depth of $17 \mathrm{~m}$ ). The trophic state of the lake was determined as hypertrophic (Sobczyński and Joniak 2009). The cormorants have regularly been observed on the lake since 2006 . They have established a roosting colony on the north shore of Castle Island (1.55 ha). The number of cormorants in the colony is still growing - the maximum number in the study (2009-2011) was 172 individuals.

Lake Ostrowiec is a large (387 ha) and deep $(28.5 \mathrm{~m})$ lake located in the Drawa National Park. The trophic state of the lake is meso-eutrophy. The cormorant colony is located on Lech Island - an area of about 1 ha (Fig. 1). Cormorants have inhabited the island for over 50 years. Their number usually does not exceed 300 pairs. During the investigations (20092011) about 160 breeding pairs were observed on this site.

\section{Methods}

Investigations on colonies located on Lakes Ostrowiec, Góreckie and Chrzypsko were conducted between April 2009 and December 2011. For the microbial analysis samples were collected bimonthly from: (i) groundwater from the area of colonies (from piezometers) and at control sites unaffected by cormorants, (ii) lake waters in the transect (shore zone

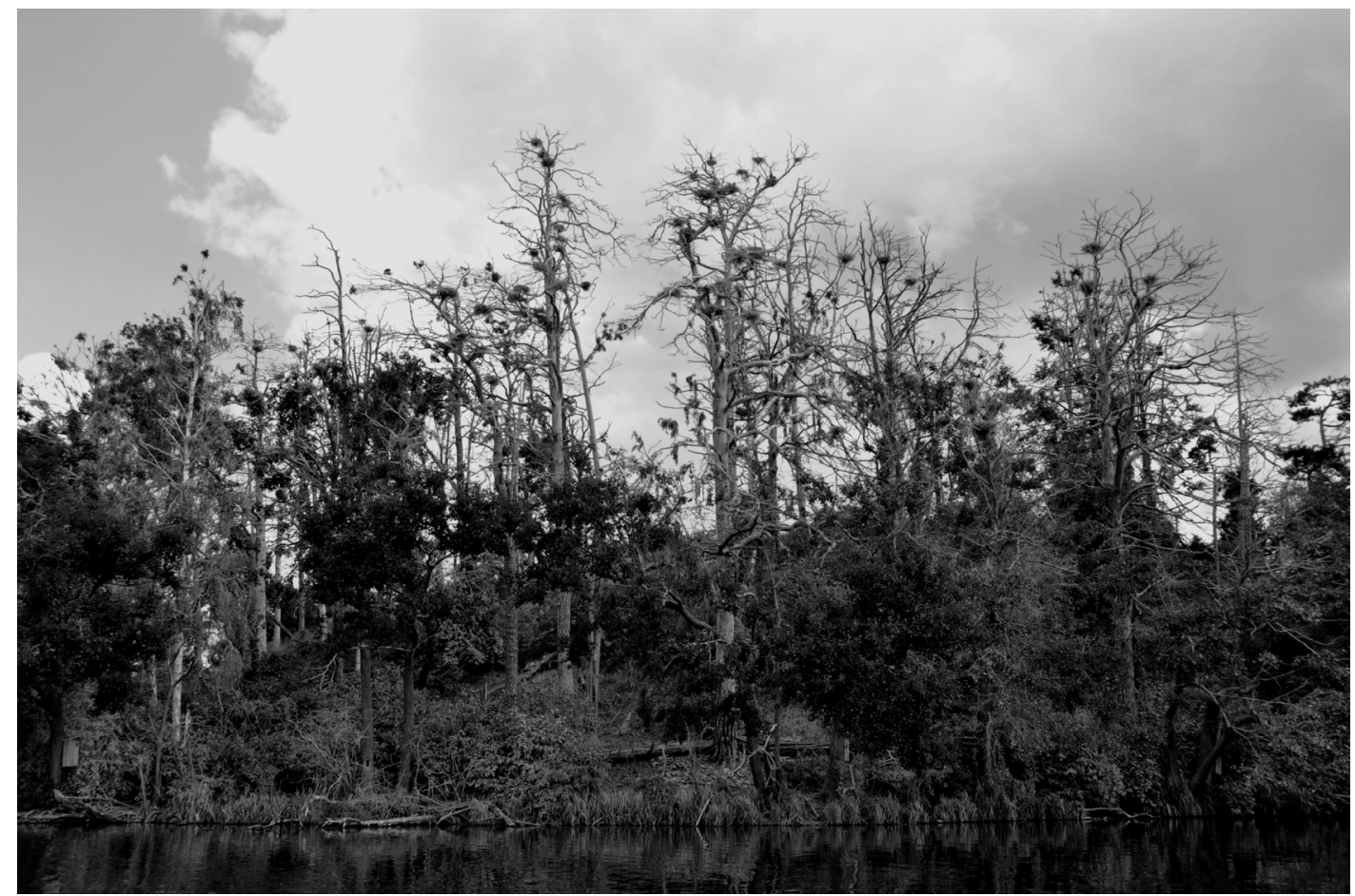

Fig. 1. Cormorant colony on Lake Ostrowiec 
near the colony, $50 \mathrm{~m}$ from the colony, $100 \mathrm{~m}$ from the colony and from the central part of the lake).

Samples for microbial analyses were collected in sterile vessels and transported to the laboratory under refrigeration $\left(4-6^{\circ} \mathrm{C}\right)$. The detection of coliforms and E. coli was performed using the Colilert-18 test by IDEXX - a method approved by Standard Methods for the Examination of Water and Wastewater [APHA 2005]. The results were given as Most Probable Number (MPN) of bacteria per $100 \mathrm{~cm}^{3}$. For the statistical analysis of data, the STATISICA 8.0 software was used.

\section{Results}

The results show that cormorants have a significant impact on the coliform contamination of the groundwater. Compared to control sites statistically significantly higher densities of the investigated bacteria (given as MPN) were found in the groundwater under the cormorant colonies (Table 1). The highest numbers of bacteria were observed in the groundwaters collected from the most abundant breeding colony (Lake Octrowiec). The maximal number of bacteria found in these samples exceeded 80000 MPN per $100 \mathrm{~cm}^{3}$ in the case of total coliforms and 6000 MPN per $100 \mathrm{~cm}^{3}$ in the case of E. coli. Significantly lower densities of the investigated bacteria were noted in groundwater beneath the roosting colony at Lake Góreckie and the newly forming breeding colony on Lake Chrzypsko (Table 1). A statistically relevant positive correlation was found between the number of cormorants in the colony and MPN for both total coliforms and E. coli (Fig. 2). The most intense microbial pollution of the groundwater collected from the area of the colony was observed during periods when the abundance of cormorants was at its peak. The highest number of investigated bacteria in the groundwater of the perennial, breeding colony on Lake Ostrowiec was noted in July 2010. At that time, the highest number of birds (mature specimens and grown nestlings) was present resulting in the highest deposition of faeces. In comparison with the breeding season, the number of bacteria rapidly dropped in the period from early autumn to spring. In the case of colonies located on
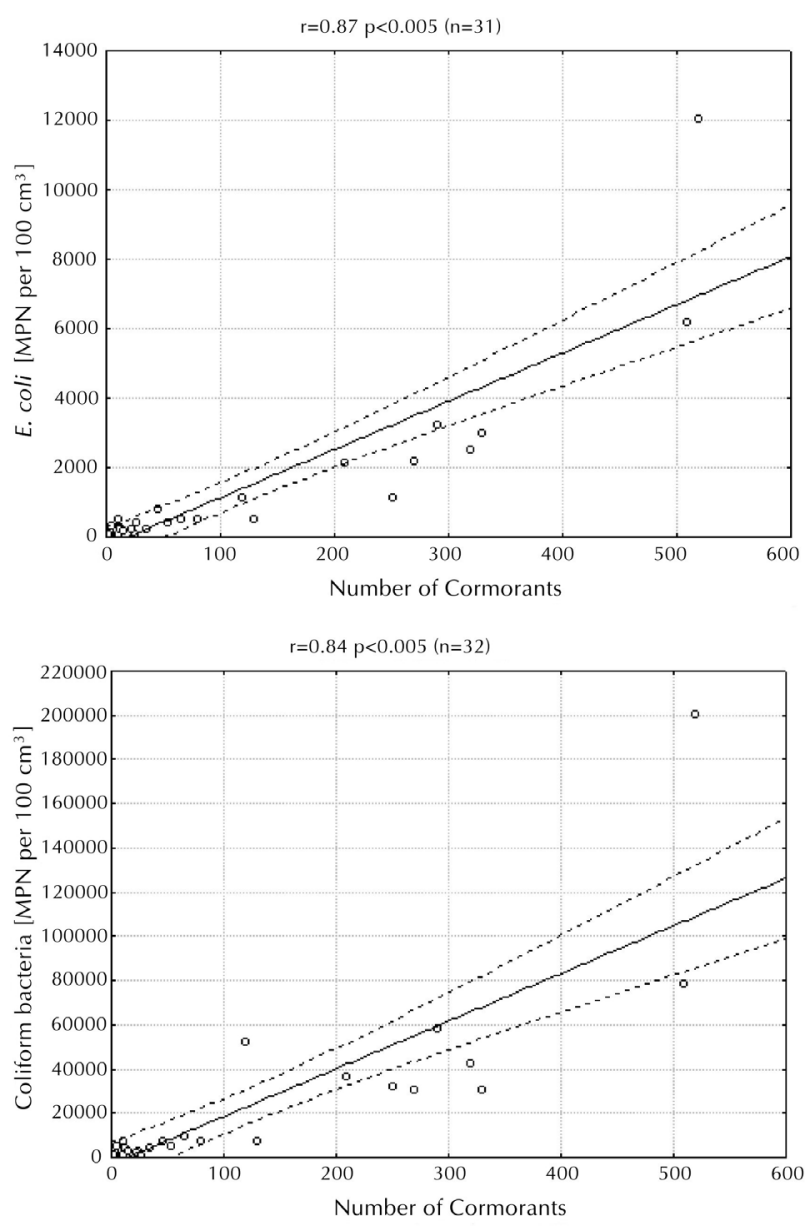

Fig. 2. Correlation between the Most Probable Number (MPN) of coliform bacteria and E. coli in groundwater under colonies and number of cormorants

Table 1. Mean density (MPN/100 $\left.\mathrm{dm}^{3}\right)$ of investigated bacteria in the groundwater under the cormorant colonies and control stations unaffected by birds and statistical significance of differences of bacteria densities between colonies and control

\begin{tabular}{lcccccc}
\hline & \multicolumn{2}{c}{ Lake Ostrowiec } & \multicolumn{2}{c}{ Lake Góreckie } & \multicolumn{2}{c}{ Lake Chrzypsko } \\
\hline & colony & control & colony & control & colony & control \\
\hline E. coli & 2394 & 92 & 475 & 52 & 256 & 75 \\
\cline { 2 - 7 } Mann Whitney U test & $\mathrm{Z}=3.17 p<0.001$ & \multicolumn{2}{c}{$\mathrm{Z}=2.97 \mathrm{p}<0.01$} & $\mathrm{Z}=2.27 \mathrm{p}<0.05$ \\
\hline Coliform bacteria & 40238 & 1040 & 5155 & 708 & 3019 & 915 \\
Mann Whitney U test & $\mathrm{Z}=3.23 p<0.005$ & $\mathrm{Z}=3.16 \mathrm{p}<0.005$ & & $\mathrm{Z}=2.47 \mathrm{p}<0.05$ \\
\hline
\end{tabular}


Lakes Góreckie and Chrzypsko, maximal densities of roosting cormorants were noted in early autumn (September) - resulting from the birds' migration after the breeding season. At the same time, the highest microbial contamination of the groundwater was found beneath the colonies.

In the case of all the investigated lakes, one general pattern of spatial distribution of the investigated bacteria was revealed - the highest densities were in groundwaters under the colony and in the surface waters. The number of bacteria fell as the distance from the colony grew (Fig. 3). Differences in the densities between the investigated stations in the transect were statistically significant (Fig. 3).

Despite one general pattern of bacteria distribution, some differences between the investigated colonies and lakes were found. In the case of Lake Ostrowiec, the number of coliforms in the littoral zone near the colony was very high (Fig. 3). In comparison with groundwater collected under the colony, the average number of E. coli was only $30 \%$ lower, although for the total coliform number the difference exceeded 50\% (Fig. 3). At the station located $50 \mathrm{~m}$ from the colony, densities of the investigated bacteria decreased. However, post hoc analysis (Dune test $\mathrm{p}>0.05$ ) revealed that there were no significant statistical differences in bacteria densities between these stations (1-3). On the other hand, a statistically significant difference (post hoc Dune test $\mathrm{p}<0.05$ ) in the number of bacteria between the stations (1-3) and that located $100 \mathrm{~m}$ from the colony (4) and the control station in the central part of the lake (5) was observed. This indicates that microbial pollution of the surface water of Lake Ostrowiec is limited to a 50 metre zone around the cormorant colony.

In comparison with Lake Ostrowiec, densities of E. coli and coliform bacteria noted in groundwaters beneath the colony at Lake Góreckie were significantly lower (approximately by 90\%). For the investigated bacteria groups, a significant statistical difference in concentrations between the stations was noted (Fig. 3 ). In this case the largest impact of cormorants on microbial pollution was noted for the groundwater and water collected from lake waters adjacent to the colony (Fig. 3). As revealed by post-hoc analyses, there was no statistical difference in total coliform and $E$. coli number between stations situated $50 \mathrm{~m}, 100 \mathrm{~m}$ from the colony and in the central part of the lake.

In the case of Lake Chrzypsko despite the fact that, according to the ANOVA analysis for the inves- tigated bacteria groups, a significant statistical difference in concentrations between the stations was noted, a post-hoc analysis indicated that for E. coli bacteria there was no statistical difference in densities in the surface water of the lake (post-hoc Dunn test $\mathrm{p}>0.050$ ). Only water near the colony was characterized by an increased number of coliform compared to farther parts of the lake (Fig. 3). However, the stated coliform density was 70\% lower in comparison with the groundwater under the colony. This shows that the small and forming cormorant colony does not affect the bacterial contamination of the lake water.

\section{Discussion}

Numerous studies concerning the impact of cormorants on aquatic and terrestrial ecosystems have determined the significant influence of these species on the nitrogen and phosphorus enrichment of the soils that lie under the colonies (Ligęza et al. 2001; Hobara et al. 2001; Ligęza and Smal 2003; Hobara et al. 2005; Osono et al. 2006). Furthermore some papers demonstrate that large aggregations of waterfowl can affect the quality of surface waters. For example Manny et al. (1994) revealed that Canada geese (Branta canadensis) are responsible for $69 \%$ of total carbon, $27 \%$ of total nitrogen and $70 \%$ of total phosphorus loads inflowing into Wintergreen Lake in Wisconsin, USA. McCann et al. (2000) calculated that a roosting colony of cormorants supplies Lake Adair in Florida, USA - a small and shallow reservoir - with $70 \%$ and $36 \%$ of its total phosphorous and nitrogen content, respectively. Therefore, the appearance of a cormorant colony near the surface waters can accelerate the process of eutrophication (Niewolak 1999; Nakamura et al. 2010). Moreover large aggregations of animals may contribute to microbial contamination of the environment because - as indicated by DeVincent (2004) - E. coli and other coliform bacteria are common components of commensal faecal flora in humans and the majority of animals. Despite this fact there are only a few studies that concerned the potential impact of waterfowl on microbial pollution of the environment including ground and surface waters.

Benton et al. (1983) noted a significant positive correlation between the number of roosting gulls and the number of E. coli in water from two lakes in Scotland. This is consistent with our study in which MPN of total coliforms and E. coli bacteria in the groundwater under the cormorant colonies was positively corre- 

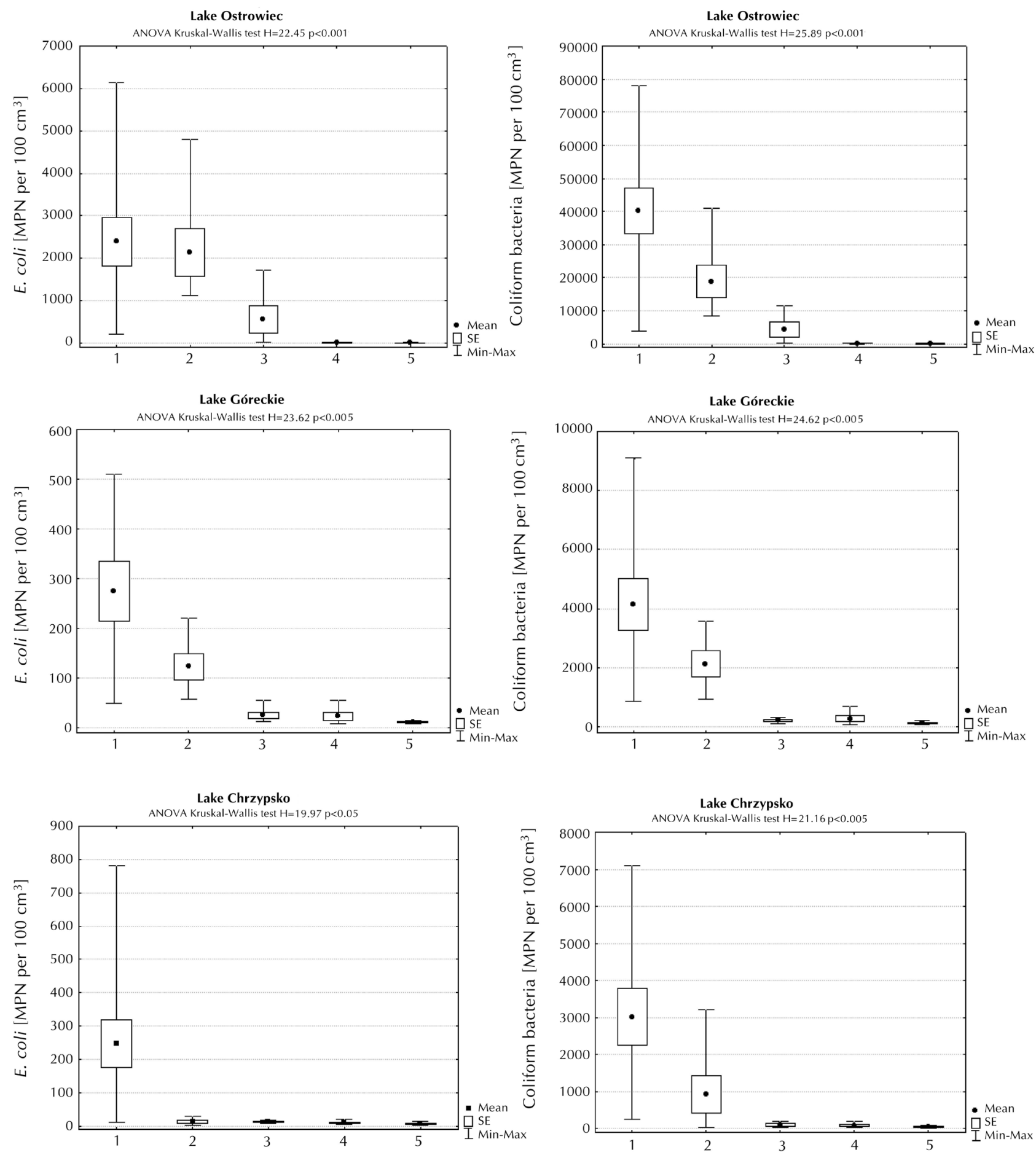

Fig. 3. The Most Probable Number of the investigated bacteria noted at sampling stations:1 - groundwater, 2 - lake near the colony, 3 lake 50m from the colony, 4 - lake $100 \mathrm{~m}$ from the colony, 5 - central part of the lake $(\mathrm{n}=30)$ 
lated with the number of birds inhabiting the colonies. Levesque et al. (1993) also noticed the considerable influence of large aggregations of waterfowl on seasonal fluctuations in the number of coliform bacteria in surface waters. In our study the lowest impact of cormorants on microbial contamination was observed for the smallest investigated colony, located on the southern island of Lake Chrzypsko. On the other hand, Klimaszyk (2012), who investigated the larger, perennial colony (175 breeding pairs) located in the northern part of this lake, found that cormorants were highly polluting the groundwater with max. 72000 MPN per $100 \mathrm{~cm}^{3}$ of coliforms and over $6000 \mathrm{MPN}$ per $100 \mathrm{~cm}^{3}$ of $E$. coli and surface water with max. $36000 \mathrm{MPN}$ per $100 \mathrm{~cm}^{3}$ of coliforms and over 4000 MPN per 100 $\mathrm{cm}^{3}$ of E. coli. This along with other results obtained in our study allows us to conclude that the number of cormorants is positively correlated with microbial pollution of the environment including ground and surface water.

It has already been observed by Niewolak (1999), Wiśniewska et al. (2007a) and Jones (2003, 2008) that littoral water located near cormorant colonies is rich in bacteria from the Enterobacteriaceae family. In our study we have demonstrated that in the case of all sampling sites the higher number of coliforms was observed in groundwater under the colony (Table 1). This resulted most likely from the high density of birds above the area and thus considerable amounts of excrement deposited on a relatively small area of the colony. Moreover large bacteria densities were also found in littoral zones situated near the cormorant colonies - resulting from direct deposition of faeces in the water during feeding activities as well as infiltration of groundwater into the lakes. It was also found that the number of bacteria decreased with the distance from the colony. This is consistent with observations by Niewolak (1999) and Wiśniewska et al. (2007b), who found a similar tendency. Furthermore we have demonstrated that the actual impact of cormorants on the microbial pollution in the aquatic environment is limited only to $50 \mathrm{~m}$ from the colony. In our study, waters adjacent to a cormorant colony often exceeded the critical value of 1000 MPN per $100 \mathrm{~cm}^{3}$ for E. coli and $10000 \mathrm{MPN}$ per $100 \mathrm{~cm}^{3}$ for coliforms. According to the Regulation of the Minister of Health (MZ 2002) it would exclude the investigated waters from any recreational use.

\section{Acknowledgments}

The research was supported by a grant from the Polish Ministry of Science No. NN305100435. The authors would also like to thank Mr Rob Kippen for the proofreading.

\section{References}

Alderisio K.A., DeLuca K., 1999, Seasonal enumeration of fecal coliform bacteria from the feces of ring-billed gulls (Larus delawarensis) and Canada geese (Branta canadensis), Appl. Environ. Microbiol. 65(12): 5628-5630.

Anderson W.B., Polis G.A., 1999, Nutrient fluxes from water to land: Seabirds affect plant nutrient status on Gulf of California islands, Oecologia 118(3): 324-332.

[APHA] American Public Health Association, 2005, Standard methods for the examination of water and waste water, APHA-AWWA-WEF, New York.

Benton C., Khan F., Monaghan P., Richards W.N., 1983, The contamination of the major water supply by gulls, Water Res. 17(7): 789-798.

DeVincent S.J., 2004, Wildlife and the ecology of antimicrobial resistance, [in:] Baer C.K. (ed.), Proc. of the Conference Health and Conservation of Captive and Free-ranging Wildlife, American Association of Zoo Veterinarians, San Diego: 51-55.

Dobbin G., Hariharan H., Daoust P.Y., Hariharan S., Heaney S., Coles M., Price L., Muckle A.C., 2005, Bacterial flora of free-living double-crested cormorant (Phalacrocorax auritus) chicks on Prince Edward Island, Canada, with reference to enteric bacteria and antibiotic resistance, Comp. Immun. Microbiol. Infect. Dis. 28(1): 71-82.

Gwiazda R., Jarocha K., Szarek-Gwiazda E., 2010, Impact of a small cormorant (Phalacrocorax carbo sinensis) roost on nutrients and phytoplankton assemblages in the littoral regions of a submontane reservoir, Biologia 65(4): 742-748.

Hobara S., Koba k., Osono T., Tokuchi N., Ishida A., Kameda K., 2005, Nitrogen and phosphorus enrichment and balance in forest colonized by cormorants: Implications of the influence of soil adsorption, Plant Soil 268(1): 89101.

Hobara S., Osono T., Koba K., Tokuchi N., Fujiwara S., Kameda K., 2001, Forest floor quality and $\mathrm{N}$ transformations in a temperate forest affected by avian-derived $\mathrm{N}$ deposition, Water Air Soil Poll. 130(1-4): 679-684.

Jones S.H., 2003, Tracking bacterial pollution sources in stormwater pipes: A final report to the New Hampshire Estuaries Project/Office of State Planning, University of New Hampshire, Durham, p. 11.

Kameda K., Koba K., Hobara S., Osono T., Terai M., 2006, Pattern of natural ${ }^{15} \mathrm{~N}$ abundance in lakeside forest ecosystem affected by cormorant-derived nitrogen, Hydrobiologia 567(1): 69-86. 
Kameda K., Koba K., Yoshimizu C., Fujiwara S., Hobara S., Koyama L., Tokuchi N., Takayanagi A., 2000, Nutrient flux from aquatic to terrestrial ecosystem mediated by Great Cormorant, Sylvia 36: 54-55.

Klimaszyk P., 2012, May a cormorant colony be a source of coliform and chemical pollution in a lake?, Oceanol. Hydrobiol. Stud. 41(1): 67-73.

Kuhn R.C., Rock C.M., Oschima K.H., 2002, Occurrence of Cryptosporidium and Giardia in wild ducks along the Rio Grande River valley in southern New Mexico, Appl. Environ. Microbiol. 68(1): 161-165.

Levesque B., Brousseau P., Simard P., Dewailly E., Meisels M., Ramsay D., Joly J., 1993, Impact of the ring-billed gull (Larus delawarensis) on the microbiological quality of recreational water, Appl. Environ. Microbiol. 59(4): 1228-1230.

Ligęza S., Smal H., Misztal M., Ciesielczuk P., Piliszczuk G., 2001, Zmiany wybranych właściwości środowiska glebowego na terenie kolonii kormoranów (Phalacrocorax carbo) w Kątach Rybackich (Changes in selected soil properties on the area of a cormorant (Phalacrocorax carbo) colony in Kąty Rybackie), Acta Agrophys. 56: 155-164 (in Polish).

Ligęza S., Smal H., 2003, Accumulation of nutrients in soils affected by perennial colonies of piscivorous birds with reference to biogeochemical cycles of elements, Chemosphere 52(3): 595-602.

Manny B.A., Johnson W.C., Wetzel R.G., 1994, Nutrient additions by waterfowl to lakes and reservoirs: predicting their effect for productivity and water quality, Hydrobiologia 279/280(1):121-132.

Marion L., Clergeau P., Brient L., Bertu G., 1994, The importance of avian-contributed nitrogen $(\mathrm{N})$ and phosphorus (P) to Lake Grand-Lieu, France, Hydrobiologia 279/280: 133-147.

McCann K.D., Olson L. D., Hardy P.G., 2000, Water quality in Lake Adair following removal of roosting cormorants, Proceedings of the Florida Lake Management Society. 2000 Annual Conference, Duck Key: 54-55.
Mulder C.P.H., Keall S.N., 2001, Burrowing seabirds and reptiles: impact on seeds and soils in an island forest in New Zealand, Oecologia 127(3): 350-360.

[MZ] Ministerstwo Zdrowia (Ministry of Health), 2002, Rozporządzenie Ministra Zdrowia z dnia 16 października 2002 r. w sprawie wymagań, jakim powinna odpowiadać woda w kąpieliskach (Dz.U. 2002, nr 183, poz. 1530) (Regulation of the Minister of Health 16 October 2002 , on requirements to be met by bathing water (Journal of Laws 2002, No 183, item 1530).

Nakamura M., Yabe T., Ishii Y., Kamiya K., Aizaki M., 2010, Seasonal changes of shallow aquatic ecosystems in a Bird Sanctuary pond, J. Water Environ. Tech. 8(4): 393401.

Niewolak S., 1999, Evaluation of pollution and the sanitary bacteriological state of Lake Wigry: Part II. Near-shore waters of Lake Wigry, Pol. J. Environ. Stud. 8(3): 169-177.

Osono T., Hobara S., Koba K., Kameda K., Takeda H., 2006, Immobilization of avian excreta-derived nutrients and reduced lignin decomposition in needle and twig litter in a temperate coniferous forest, Soil Biol. Biochem. 38(3): 517-525.

Sobczyński T., Joniak T., 2009, Differences in composition and proportion of phosphorus fractions in bottom sediments of Lake Góreckie (Wielkopolska National Park), Environ. Prot. Eng. 35(2): 89-95.

Vitousek P.M., Howarth R.W., 1991, Nitrogen limitation on land and in the sea: How can it occur?, Biogeochemistry 13(2): 87-115.

Wiśniewska H., Niewolak S., Korzeniewska E., Filipkowska Z., 2007a, Enterobacteriace family bacteria in a mesotrophic lake (Lake Długie Wigierskie) in the presence of Black cormorants, Pol. J. Natur. Sc. 22(3): 486-499.

Wiśniewska H., Niewolak S., Korzeniewska E., Filipkowska Z., 2007b, Bacteriological indicators of pollution and sanitary state of Długie Wigierskie Lake water in the presence of cormorants (phalocrocorax carbo), Arch. Ochr. Środ. 33(1): 29-44. 